Chiapas (leg. E. Matuda, 25 Mart. 1924—planta florifer); ibidem (leg. E. Matuda, j Apr. 1936-planta fructifer).

Distrib. Mexico, endemic.

Note. This interesting plant is sent to me from Mr. EiJi Matuda, a teacher of the Japanese school in Esquintla, Chiapas, Mexico, and the species is dedicated to him.

July $3,1936$.

Laboratory of Systematic Botany and Plant Ecology, Botanical Institute, Faculty of Science and Agriculture,

Taihoku Imperial University, Taihoku, Nippon.

\title{
New or Noteworthy Trees from Micronesia. XVII:
}

By

\section{Ryôzô Kanehira.}

With 7 Text-figures.

Feceived August $5,1936$.

Further material of Pandanus was secured from Micronesia through the efforts of various officials of the South Seas Bureau stationed in the Archipelago. Material from neighbouring regions is now being collected and it is planned from time to time to publish notes, descriptions and illustrations based on these specimens. It is highly desirable that numerous species be more fully illustrated, not only for the purpose of comparing these with Micronesian species but also in a study of the genus Pandanus as a whole."

\section{Section Keura.}

(164) Pandanus rotundatus Kanen. in Bot. Mag. Tokyo 49 (1935) 427. f. 35 .

Jaluit No. 3515. Jaluit District Office, Feb. 13, 1935. Vern. name: "Buken" (Jaluit). A new locality for the species. The type was from Ponape. locally known as "Majokjok".

(165) Pandanus jaluitensis Kanerr. l. c. 103, f. 9, ibid. 190.

Irokiel No. 3643, rern. nume: "Deberik". Kusai No. 2804, vern.

* The expenses in eomnection with a study of the Pandanaceae of Micronesia were partly defrayed by a grant from the Teikoku-Gakushi-In (Imperial Academy of Science). 
name: "Meufeufol"; No. 2803, vern. name: "Korsa". Ponape No. 3453, vern. name: "Pacheren". Jaluit No. 2791, vern. name: "Joene".

The type was from Jaluit, the species extends to Kusai and Ponape.

(166) Pandanus Hosinoi Kanerr. 1. c. 103, f. 8.

Mokiel Island No. 3458, vern. name: "Neketak'.

The type was from Ponape.

(167) Pandanus macrocephalus KaneH. 1. c. 428, f. 34.

Jaluit Island No. 2794, vern. name: "Cruenu'.

The type was from MIokiel Island, also known from an unnamed island near Ponape.

(168) Pandanus trukensis Kaneir. l. c. 190, f. 21.

Jaluit No. 3513, vern. name: "Agiwirok'. Truk, Tol No. 3491, rern. nume: "Fazeira".

The type was from Truk. It extends to Kusai and Jaluit.

(169) Pandanus pulposus Martelli in Webbia 4, 2 (1914) 409, t. :38. f. 1-3; KANEH. l. c. 110, f. 13.

Ponape No. 3459 , vern. name: “Jomineia".

The type was from Radak, Marshall Islands. A new locality for the species.

(170) Pandanus cylindricus Kaneh. 1. c. 63, f. 3.

Mokiel Island No. 3461, vern. name: "Toap".

The type was from Ponape. A new locality for the species.

(171) Pandanus rectangulatus KaneH. in Journ. Dept. Agr. Kýs:n Imp. Univ. Vol. 4 (1935) (Enum. Micr. Pl.) 264, nom. nud. (Fig. 51) Syncarpiis subglobosis, pendulis, solitariis, phalangiis circiter $40 \sim 45$, obovoideis, $6.5 \mathrm{~cm}$. longis, usque ad $5 \mathrm{~cm}$. latis, partibus $1 / 3$ superioribus liberis, vertice truncatis vel paullo convexis, basi abrupte angustatis, loculis j-8, plerumque 6, subaequalibus, paullo convexis vel partibus centralis leviter depressis sed sulcis profundis et distinctis, stigmate suberecto. Endocarpium osseum, in parte $1 / 3$ superiore positum, superne rimosum, inferne subtruncatum, mesocarpium superum lacunosum, inaequale, mesocarpium inferum fibrosum, $4 \mathrm{~cm}$. longum.

The species is no doubt allied to Pandanus brachypodus KaneH. but is easily recognizable by its truncate phalanges and much more numerous locules.

The size of syncarps is variable, commonly $10-15 \mathrm{~cm}$. in diam. 
No. 3469. Enchabi Island, OIrba Sept. 1934, locally known as "Patyaplip".

No. 3479 ("Olwo"), No. 3477 ("Demesyô"'), No. 3473 ("Parkup"), Enchabi Island Oнва Sept. 1934. These are all apparently referable to a single species.

\section{(172) Pandanus Menne}

KANEIr. l. c. 262 (Fig. 52).

Syncarpiis ut videtur subglobosis, circiter $25 \mathrm{~cm}$. dia. metro, phalangiis obpyriformibus, lateraliter compressis, $10 \mathrm{~cm}$. longis, usque ad $7 \mathrm{~cm}$. latis, $5 \mathrm{~cm}$. crassis, partibus $1 / 3$ superioribus liberis, vertice subtruncatis, basi sensim angustatis, loculis

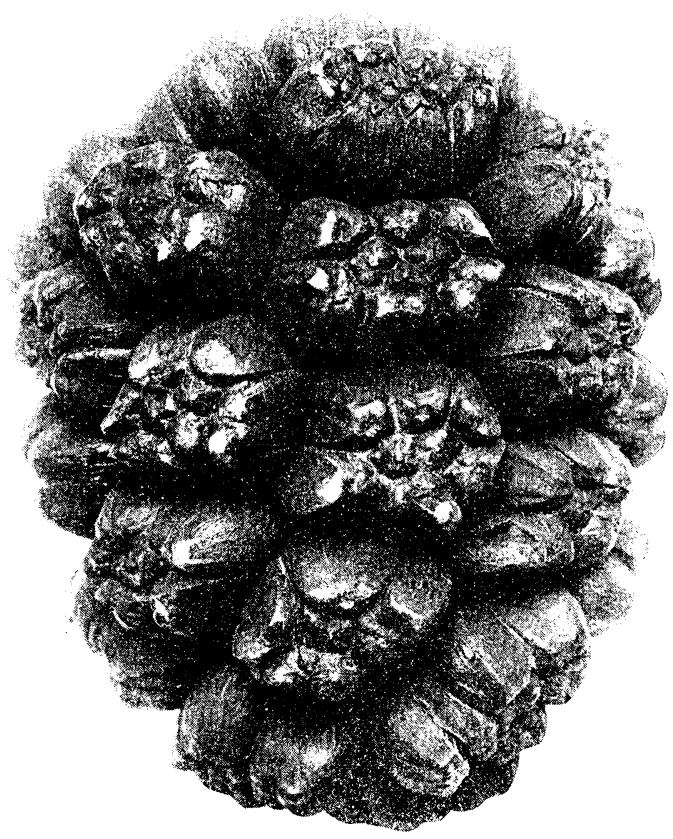

Fig. 51.

Pandanus rectangulatus KANEH. $\times \%$.

8 vel 9, irregulariter clispositis, inaequalibus, exterioribus multo majoribus, sulcis haud profundis, stigmate minuto, paullo suberecto. Endocarpium osseum in parte $1 / 3$ superiore positum, superne rotundatum, inferne subtruncatum, $4 \mathrm{~cm}$. spissum. Mesocarpium inferum fibrosum, $5.5 \mathrm{~cm}$. longum.

Phalanges laterally compressed, their upper prarts rounded, the base gradually narrowed, locules very irregular in shape, slightly convex, shallowly sulcate or nearly plane, stigma small,

Fig. 52. Pandanus Menne KANEH. (4517) $\times 1 / 3$. 
hardly erect.

No. 3517 Jaluit, Jaluit District Officer, Sept. 1934; locally known as "Menne".

A species well marked by its laterally compressed phalanges with shallow sulci and slightly elevated and variable locules, the outer ones much larger than the inner ones.

\section{Section Bryantia.}

(173) Pandanus Cominsii Hemsl. Hook. Ieon. (1900) t. 2654 ; Marteli in ENGL. Bot. Jahrb. 49 (1912) 66, Webbia 4 (1914) t. 26, f. 20; Kaneh. in Bot. Mag. Tokyo 49 (1935) 356, f. 31, Enum. Micr. Pl. (1935) 260.

Pandanus Hollrungii WARB. in ENGI. Pflanzenr. (Pandanaceae) (1900) 71, f. 19, E-J, form. caroliniana Marteus in ENGL. Bot. Jahrb. 49 (1912) 66 ; Kaneh. Enum. Micr. Pl. 261.

Truk No. 3489, Ponape No. 3705.

Pandanus Cominsii is reported to occur in Solomon Islands, Bismarck Archipelago, New Hebrides and Caroline Islands (fide Martienis), while the type of Pandanus Hollrungii Warb. was from New Guinea and the forma caroliniana was from Truk (Caroline Islands).

By comparing specimens from Truk and Ponape with deseription and figures of the above species and form as characterized by WARBURG and Marteli, I fail to find any distinct characters, and I think that $P$. Hollrungii and its forma caroliniana are both synonymus of $P$. Cominsii.

\section{Section Ryckia.}

(17 4 ) Pandanus furcatellus Martella in Webbia 1 (1905) 368, t. 29, f. 9-12, 4 (1913) 15.

Tamadao, Cochin-China, B. Hayata Aug. 1, 1917. The specimen in the Tokyo Imperial University Herbarium.

Identified by the description and figures of Martelli. The type was from Kien-Khé, Tonkin, Cochin-China. Distrib. Known only from CochinChina.

(175) Pandanus Yamagutii Kanerr. sp. nov. (Fig. 54).

Syncarpiis ut videtur solitariis, erectis, terminalis, globosis, circiter 8 cm. diametro, drupae late clavatae, obscure rhomboidae, $3 \mathrm{~cm}$. longae, $1.5-$ $1.7 \mathrm{~cm}$. latae, pentaexagonae, apice subrotundatae, basi attenuatae, in tertia superiori parte a pileo indutae, pileo coriaceo, 12-15 cm. longo, inaequilateraliter late cupulari-pyramidato, penta-hexagono, in stylum latiusculum. 


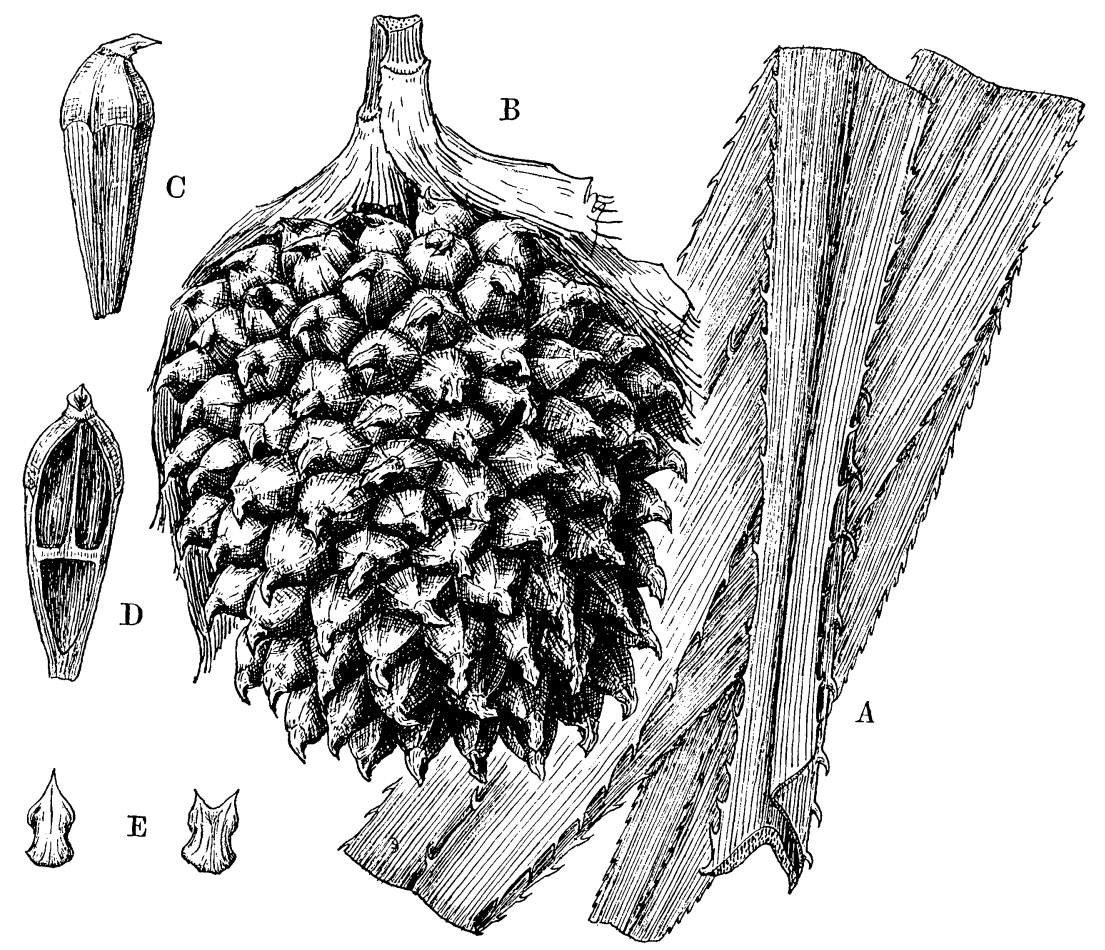

Fig. 53. Pandanus fureatellus Martelis.

A Leaf $\times 1 / 3$. B Syncarp $\times 2 / 3$. C Drupe $\times 3 / 4$. D Longitudinal section of the same $\times 3 / 4$. E Different types of stigma $\times 1$.

nitidum, bi- vel tridentato-fureatum, externe subplanum, sursum paullo curvatum, superficie stigmatica pèr totam superiorem partem styli extensa.

No. 3721 Truk, Truk District Office, Sept. 1935.

The plant is characterized by its large flattened 2 or 3 forked stigma. The section is new to the flora of Micronesia. It is noteworthy that the species representing this section are recorded chiefly from the Asiatic Continent and the Philippines and no species are known from the eastern part of the last-mentioned Islands. It is named in honour of Mr. Yuzaburô Yamagut, the Chief of the Truk District Office, through whose assistance, many specimens were collected in Truk Island. The description is based on a single specimen, its habitat no well being known. Drupes of the type are somewhat immature, but they are characterized by the very thick exocarp which encloses the drupe, large fibrous mesocarp, and a small seed which is embedded at the base of the drupe. 


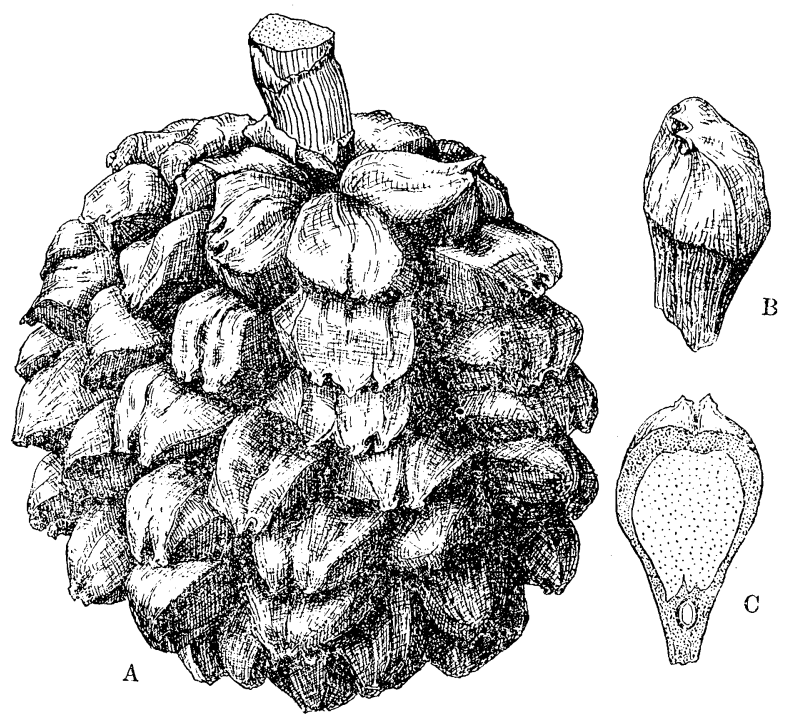

Fig. 5it. Pandanus Yamagutii Kanem. (3721).

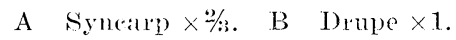

(C Tongitudinal section of the same $\times 1$.

\section{Section Acrostigna.}

(176) Pandamus Gibbsianus Martella in Webbia 4, 1 (1913) 15, t. 41, f. 7-9; Grbss in Journ. Soe. Bot. 42 (1914) 170; Mewr. Bib. Ennm. Bern. Pl. (1921) 35, Pl. Elm. Born. (1929) 16.

No. 3733 Tawao, Borneo (Tawau Rubber Estate) K. Mafda Nov. 6 , 1935.5 .

The type was from Borneo. The specimens preserved in the Forest Inst. Kyusyu Imp. Univ.

"An erect shrub-like tree on steep forested bluffs. Stem few, sevoral inches thick, with short prop roots. Iueaves $3 \mathrm{~m}$. long, somewhat glaucous beneath when fresh. Sycarps 3, globose, the peduncles about $30 \mathrm{~cm}$. long, subpendulous" (Merrisu l. e.). Identified from the description and figures.

\section{Section Lophostigma.}

(177) Pandanus Syozoi Kaneir. sp). nov. (Fig. 56, 57).

Arbor magna, $10 \mathrm{~m}$. alta (fide (Oинмото), saepe ramosa. Folia crasse coriacea, latissime linearis, ultra $2.3 \mathrm{~m}$. longa, basin $12 \mathrm{~cm}$. lata, apicem versus Jonge-acuminata, basi sensim angustato-attenuata, utrinque longitudinaliter nervoso-striata, costa subtus ultra $3 / 4$ superiori parte spinis brevissimis remotis armata, marginibus superioribus et inferioribus spinis 


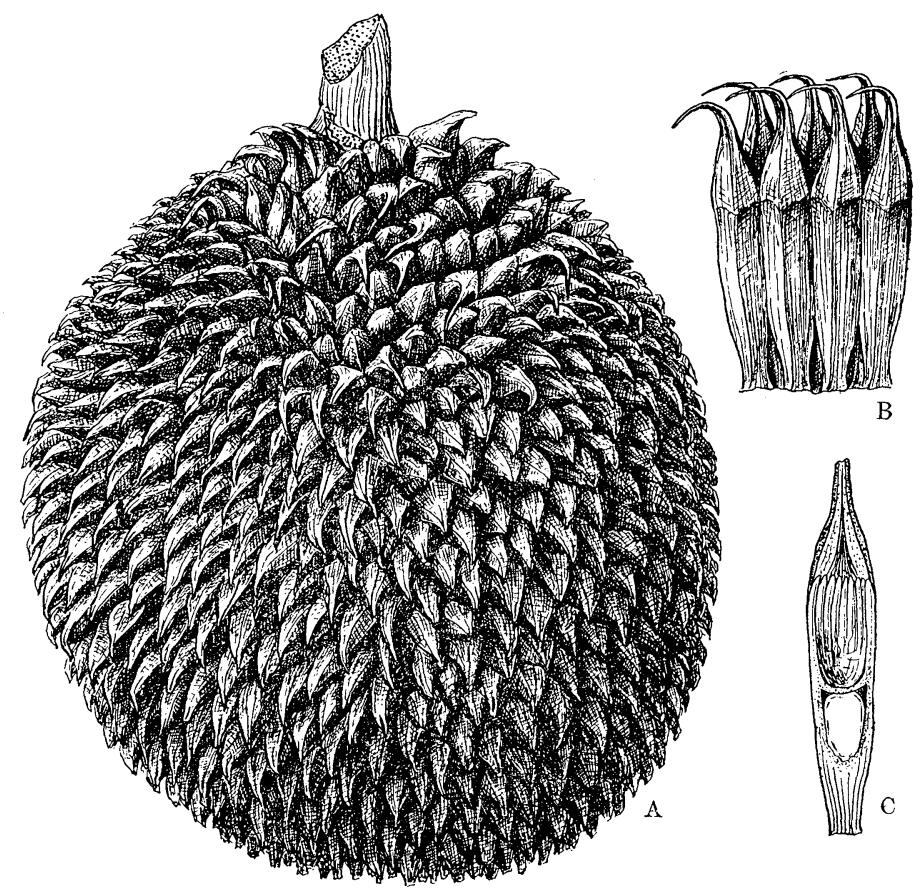

Fig. 5.). Pandanus Gibbsianus Martelt.

A Synculp $\times \%$. B Drupes $\times 1$. ( ( $^{\circ}$ Longitudinal seetion of the same $\times 1.2$.

brevissimis minutis reductis armata, caeterum plana. Infructescentiis racemosis, $40 \mathrm{~cm}$. longis, erectis, rachis trigono-teretibus 2 cm. crassis, syn(arpiis ambitu elipssoideis, longe pedunculatis, pedunculis $5-7 \mathrm{~cm}$. longis, siceo distincte trigonis, 5-6 cm. longis, $4.5 \mathrm{~cm}$. latis, drupis immaturis ovoideo-claviformis, leviter lateraliter compressis, 15 mm. longis, 6-7 mm. latis, minute-suleatis, ultra $3 / 4$ partibus superioribus liberis, stigmate eccentrico, plano, plus-minusve eurvato, $3 \mathrm{~mm}$. diametro.

No. 3727 (Okamoto No. 6) September 22, 1935, s. Okaмoto. At the imner margin of mangrove and in wet swampy jungle, near Garamiscan, Babeldaob, Palau.

I tall tree about $10 \mathrm{~m}$. high, stem often branched, leaves large, reflexed from the middle and upper part pendulons.

This species is named in honour of irr. Syôzô Oramoto who located it and collected specimens on his way to Garamiscan by a cance during a heavy rain. The description is based on somewhat immature specimens but as it may be very difficult to locate the tree again and secure more complete material, I have dared to name and describe this interesting species. 


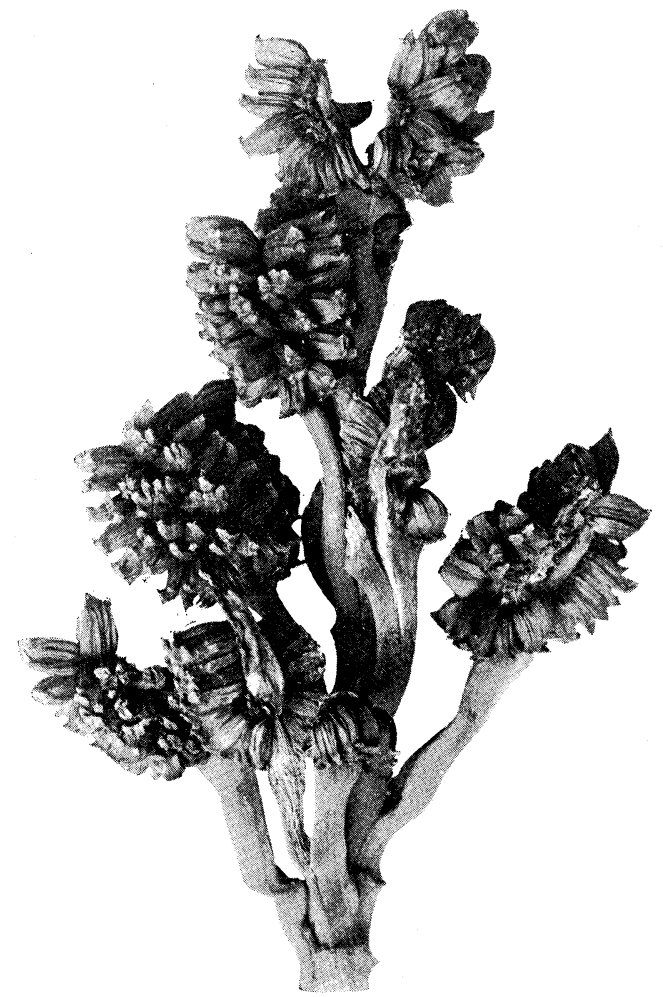

Fig. 56. Pandanus Syozoi KANEH. $\times 2 \%$.

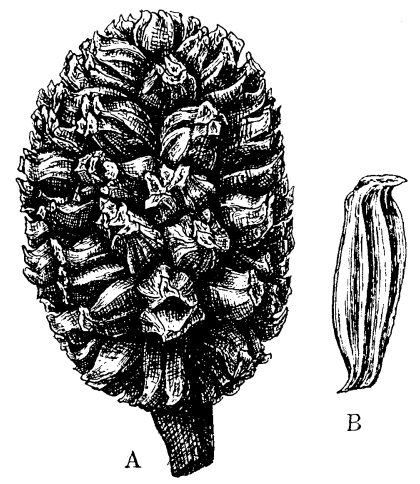

Fig. 57. Pandanus Syozoi Kaxerr. A Syncarp $\times \%$.
B Drupe $\times 1$.

It is allied to Pandanus viscidus BaLf. of New Caledonia but is distinguished by its larger stigma. The second species of the Section Lophostigma from Nicronesia.

The species apparently belongs to the Section Lophostigma, as I interpret WARBURG's characters, because of its unilocular drupes and its horizontally affixed and upwardly ascending plane stigmas. WARBURG's sections are principally based on morphological characters of the srncarps and phalanges or drupes. Because of the lack of complete specimens the infructescence characters were not stressed by WARBurg. As the latter characters are variable, even in the same section, I am somewhat doubtful as to whether or not the present species is properly placed in Lophostigma; more complete material may lead to some other disposition of it.

\section{Section Hombronia.}

(178) Pandanus dubius Spreng. Syst. 3 (1826) 897 ; Kurz in Joum. Bot. 5 (1867) 127, t. 64, f. 1 \& 2; WArb. in Krieger, Neuguinea (1899) t. 7, et Engl. Pflanzenr. (Pandanaceae) (1900) 50, f. 1 \& f. 14 A-D ; Martelli in Webbia 4 (1913) 12 ; Merr. in Philip. Journ. Sci. 9 (1914) Bot. 48; KaneH. in Bot. Mag. Tokyo 45 (1931), 273 et Fl. Micr. (1933) 61, f. 2. 
Truk No. 3494, vern. name: "Pohk";

Palau No. 2135, vern. name: "Poko";

Kusai No. 3507, vern. name: "Meu-yok";

Saipan No. 35̄30, vern. name: "Pafung"'.

Distrib. Java, Borneo, Moluceas, Celebes, Papua, Bismarck Archipelago, Philippines, and New Hebrides.

The shape of drupes is very variable and Pandunus compressus MARTLLL (patria ignota) is most likely a synonym of the present species.

(To be continned.)

\section{Gymnosporangium of Japan. II.}

By

\section{Naohide Hiratsuka.}

With 1 Plate.

Received May $23,1936$.

2. Gymnosporangium formosanum Hiratsuka, f. et HasHoKa in Bot. Mag. 'Tokyo, XLIX, p. 21 (1935).

Habitat. Teleutosori on Juniperus squamata LAMBserT (J. morrisonicola Hayata) (Niitaka-byakushin).

Formosa:-Taiwan: M.t. Niitaka (Shuzan) (Y. Hasmoks, type !).

Distribution. Japan (Formosa).

The thick-walled teleutospores of this fungus are readily distinguishable from those of all other species of this genus, now known, by their peculiar shape and their thickened epispore. It is only known from its type locality, as far as the writer is aware. The aecidial connection of this fungus has not demonstrated by cultures and no field observations have been made.

3. Gymnosporangium nipponicum Yamada in Hiratsuka, f. in Nem. Tottori Agric. Coll. III, p. 143 (1935).

Habitat. Aecidia on Sorbus Aucuparia L. (Nanatamado) (Pl. VIII, Fig. 3).

Honshî:-Rikuchû: Morioka (G. YanadA). 